$10 / 195085$

Report No.

WR-B-96-04
U.S. Department of Inergy

Office of Inspector General

October 1995

Report on

\title{
Audit of Fuel Processing Restoration Property
}

MASTER

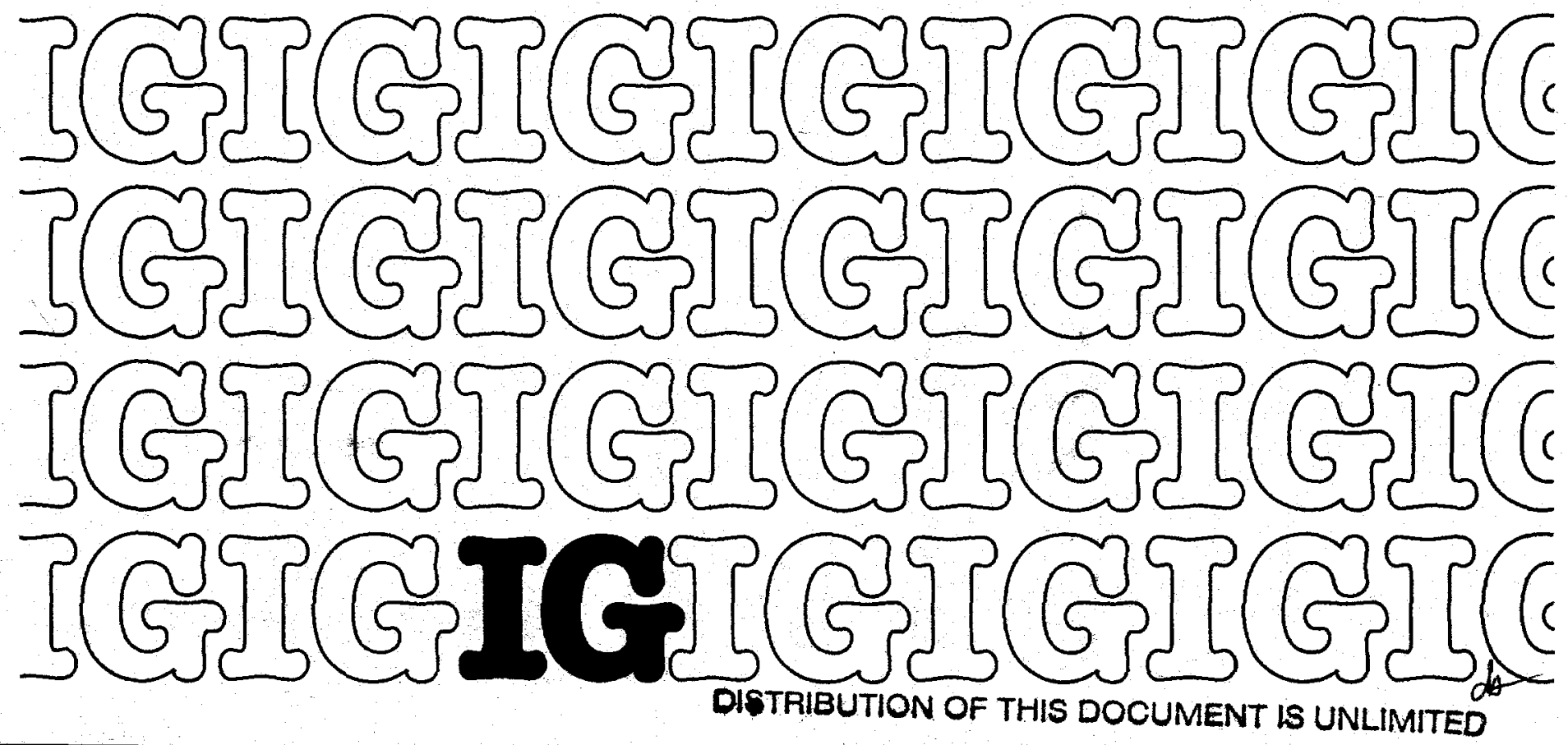


The office of Inspector General wants to make the distribution of its reports as customer friendly and cost effective as possible. Therefore, this report will be available electronically through the Internet five to seven days after publication at the following alternative addresses:

Department of Energy Headquarters Gopher gopher.hr.doe.gov

Department of Energy Headquarters Anonymous FTP vml.hqadmin.doe.gov

Department of Energy Human Resources and Administration Home Page http://www.hr.doe.gov/refshelf.html

Your comments would be appreciated and can be provided on the Customer Response Form attached to the report.

This report can be obtained from the U.S. Department of Energy

office of Scientific and Technical Information P.0. Box 62

Oak Ridge, Tennessee 37831 


\section{DISCLAIMER}

Portions of this document may be illegible in electronic image products. Images are produced from the best available original document. 
U.S. DEPARTMENT OF ENERGY

OFFICE OF INSPECTOR GENERAL

\section{AUDIT OF FUEL PROCESSING}

\section{RESTORATION PROPERTY}

Report Number: WR-B-96-04

Date of Issue: October 20, 1995
Western Regional Audit Office

Albuquerque, NM 87185-5400 


\section{AUDIT OF FUEL PROCESSING}

\section{RESTORATION PROPERTY}

\section{TABLE OF CONTENTS}

Page

SUMMARY ..................... 1

PART I $\quad$ A APPROACH AND OVERVIEW.............. 2

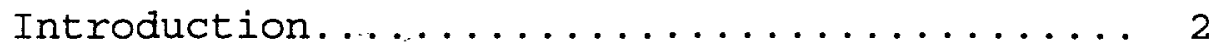

Scope and Methodology................ 2

Background......................... 3

Observations and Conclusion............4

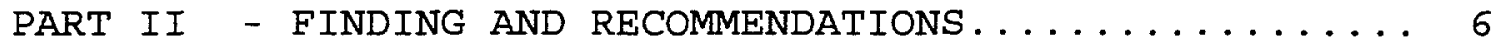

Management of Fuel Processing

Restoration Property.............. 6

PART III - MANAGEMENT AND AUDITOR COMMENTS......... 11 


$\frac{\text { U.S. DEPARTMENT OF ENERGY }}{\text { OFFICE OF INSPECTOR GENERAL }}$
OFFICE OF AUDIT SERVICES
WESTERN REGIONAL AUDIT OFFICE

AUDIT OF FUEL PROCESSING RESTORATION PROPERTY

Audit Report Number: WR-B-96-04 October 20, 1995

\section{SUMMARY}

In April, 1992, due to a diminished need for reprocessed uranium, the secretary of Energy terminated the Fuel Processing Restoration (FPR) project. The termination left management and operating (M\&O) contractors at the Idaho National Engineering Laboratory (Laboratory) with over $\$ 54$ million in tools, equipment and material to be retained, utilized or disposed of. The objectives of the audit were to determine whether FPR property was adequately accounted for and whether the property was properly redistributed or excessed when the FPR project was terminated.

Although some of the FPR property was effectively utilized within the Laboratory, the Department of Energy (Department) and its contractors did not completely and accurately account for the \$54 million of property and promptly redistribute or appropriately excess the property. A significant amount of the property reviewed was not accounted for in the Department's approved property management system. In addition, we identified over 2,700 stock items which had neither been identified for redistribution nor excessed. Lastly, only a limited amount of property distributed outside of the Laboratory was ever placed in the Department's excessing system which makes property available throughout the Department and to other Federal agencies.

We recommended that the Manager, Idaho Operations Office, ensure that a wall-to-wall inventory be performed on property remaining at the Laboratory; all FPR property be properly marked, tagged, and accounted for in the Laboratory's approved Government property record; and, all surplus property be excessed in accordance with applicable rules and regulations.

Management concurred with the finding and recommendations presented in the report and has already initiated corrective actions in response to the recommendations.

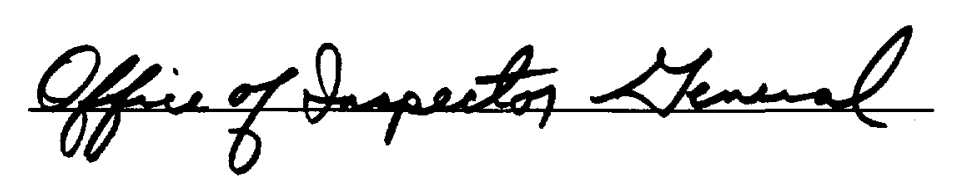




\section{$\underline{\text { PART I }}$ \\ APPROACH AND OVERVIEW}

\section{INTRODUCTION}

The Office of Inspector General has issued numerous reports identifying opportunities for the Department of Energy to improve its management of personal property. In March 1994, we issued a "Summary Report on the Department of Energy's Management of Personal Property," (DOE/IG-0344) highlighting property issues spanning almost a decade. Consistent with our earlier work, the purpose of this audit was to determine whether the Department, Idaho Operations office and its M\&O contractors effectively managed the property related to the FPR construction project upon termination. Specifically, our objectives were to determine whether: (1) FPR property at the Laboratory was adequately accounted for; and (2) property was properly redistributed or excessed when the Department terminated the FPR project.

\section{SCOPE AND METHODOLOGY}

The audit was performed at the Laboratory from September 1994 to May 1995. To accomplish the audit objectives, we interviewed key personnel at all management levels and reviewed:

- Federal and Departmental regulations governing property accountability and utilization of excess property;

- documentation and controls used by Idaho and its management and operating contractors to account for FPR property remaining upon project termination;

- Department approved property system and inventory records;

- contractor's inventory reports; and,

- excessing procedures and documentation.

During our audit, we reviewed FPR property controls by examining different items acquired for the FPR construction project. The total universe was segregated into two separate groups of property: government furnished equipment, i.e., property purchased directly for a facility, and subcontractor acquired property.

Government furnished equipment consisted of approximately 3,040 items valued at $\$ 32$ million. From this, we judgmentally selected for review 210 capital items valued at $\$ 20.5$ million. Subcontractor acquired property consisted of approximately 8,360 
items valued at nearly $\$ 22$ million. From this, we judgmentally selected for review 266 capital and sensitive items valued at over $\$ 655,000$.

The audit was performed in accordance with generally accepted Government auditing standards for performance audits and included such tests of internal controls and compliance with laws and regulations to the extent necessary to satisfy the objectives of the audit. Accordingly, the audit included an assessment of significant internal controls over the receipt, accountability, and excessing of FPR property. We did not rely extensively on computer processed data and, therefore, did not fully examine the reliability of the data. Because our review was limited, it would not necessarily have disclosed all internal control deficiencies that may have existed at the time of our audit.

\section{BACKGROUND}

In 1982, plans for constructing the FPR facility began at the Laboratory. The reason for constructing this facility was to enhance the Laboratory's ability to provide fuel reprocessing capabilities for recoverable irradiated fuels within the Departments of Energy and Navy up through the year 2030 . Construction on the facility began in Fiscal Year 1986 with a target completion date of 1994. During the first part of Fiscal Year 1992, the project was rebaselined due to significant cost and schedule overruns. In April 1992, however, the Secretary of Energy terminated the FPR project because of a diminished need for reprocessed uranium.

Subsequently, project managers from the Idaho Operations Office and two of its M\&O contractors, Westinghouse and MKFerguson, drafted a Utilization and Disposal Plan for acquired FPR property. The plan outlined each contractor's responsibility to ensure that the FPR property was either retained, utilized, or disposed of in an economical and efficient manner. According to the plan, the Idaho Operations office was responsible for providing general guidance for property disposition and approving the Utilization and Disposal Plan. Westinghouse was responsible for the accountability and disposition of $\$ 32$ million of government furnished equipment related to the FPR project. MK-Ferguson was assigned the responsibility of negotiating the termination agreements with six subcontractors involved in the project. After the final settlement, MK-Ferguson assumed control of approximately $\$ 22$ million of subcontractor acquired property including tools, equipment and materials.

EG\&G Idaho, Inc. (EG\&G), the common support contractor, was responsible for administering the Department approved Property and Equipment Control system (property system) for the Idaho Operations office and excessing any unneeded property maintained at the Laboratory. All property acquisitions or dispositions by other M\&O 
contractors were to be reported to EG\&G who would update the property system based on reported actions. Excess property transferred to EG\&G was placed in the Department's Reportable Excess Automated Property System (excess system) for possible use by another Departmental facility or to be sold as scrap.

On October, 1, 1994, a contract was awarded to Lockheed Idaho Technologies Company (Lockheed) which consolidated management and operating functions of five contractors to one consolidated contract. Lockheed accepted responsibility for all contractorcontrolled property. However, due to inconsistencies in contractor inventories, Lockheed had not accepted liability for property inventories from incumbent contractors. Liability for the property will be assumed by Lockheed upon completion and acceptance of the Laboratory's wall-to-wall baseline inventory. In fact, Lockheed initiated a wall-to-wall inventory of FPR property during our audit to determine the quantity of FPR property located at the Laboratory. Although Lockheed was not responsible for any conditions cited in the report, they will be tasked by the Idaho operations office to take the corrective actions required by our report recommendations.

\section{OBSERVATIONS AND CONCLUSIONS}

Project managers at the Laboratory have saved the Department a substantial amount of money by utilizing some of the property from the FPR contract termination. In fact, over 100 different individuals at the Laboratory have requested items from the FPR property inventory. One organization alone estimated a cost savings in excess of $\$ 600,000$ for its projects by utilizing the available material to assist in construction and modification of research labs.

While we recognize that some Laboratory managers efficiently utilized the FPR property, the Department and its contractors have not completely and accurately accounted for the $\$ 54$ million in FPR property and did not promptly redistribute or appropriately excess FPR property. For example, at least $\$ 4.2$ million of $\$ 21.2$ million (20 percent) of FPR property reviewed was not adequately accounted for in the Department's property management system and only 44 of the 1,490 items excessed outside the Laboratory were ever entered into the Department's system for excess property. These conditions occurred because project management did not account for the property in accordance with established Departmental and local property management guidelines. Although we were able to physically locate most of the property we tested, the lack of accountability rendered the property readily susceptible to undetected theft or loss. In addition, at least $\$ 43,000$ in property items were purchased by the Laboratory when these items were already available in the FPR inventory. This may be an indication of a significant problem considering that there are approximately 2,700 different stock items still on hand which have 
not been identified for reutilization or excess. Finally, improper accounting of property and equipment could result in a material misstatement on the property section of Idaho's financial records.

In our opinion, the finding in this report disclosed material internal control weaknesses that the Department should consider when preparing its year-end assurance memorandum on internal controls. 


\section{$\underline{\text { PART II }}$}

\section{FINDING AND RECOMMENDATIONS}

\section{Management of Fuel Processing Restoration Property}

\section{FINDING}

Departmental property management regulations require that property be completely and accurately accounted for. These regulations also emphasize the importance of promptly redistributing or excessing surplus property to ensure efficient use of available resources. However, as the Department and its contractors took custody of nearly $\$ 54$ million in FPR property, they did not completely and accurately account for, promptly redistribute, or appropriately excess FPR property. For example, at least $\$ 4.2$ million in FPR property was not accurately accounted for and excessing procedures were not followed. This occurred because project management did not adhere to either established Departmental property requirements or local property management guidelines to control FPR property. A significant amount of property was unaccounted for and unutilized. In addition, the Department procured over $\$ 43,000$ in property which was already available from the FPR project inventory. Finally, property was subject to an increased potential for loss or theft. Since our review covered only $\$ 21.2$ million of the $\$ 54$ million in FPR property, these numbers will likely increase when Lockheed completes its inventory. This, in turn, could have a material effect on the financial statements if these assets are not properly recorded.

\section{RECOMMENDATIONS} that:

We recommend that the Manager, Idaho Operations Office, ensure

1. a wall-to-wall inventory of all remaining FPR property at the Laboratory is completed;

2. all FPR property transferred to end users or retained within the Laboratory, is properly marked, tagged, and accounted for;

3. all FPR accountable property is placed in the Laboratory's Department approved property record; and,

4. all surplus property, for which retention cannot be justified, be excessed in accordance with applicable rules and regulations. 


\section{MANAGEMENT REACTION}

Management concurred with the finding and recommendations, and has initiated corrective actions. Detailed management and auditor comments are provided in Part III of this report.

\section{DETAILS OF FINDING}

Departmental policy requires the establishment of a program which ensures that complete and accurate accountability of government property is maintained. In addition, Departmental regulations require that excess property be promptly identified so that excess property is available for use by others. Further, any deviation from Departmental policy requires approval of the Director of Procurement and Assistance Management.

\section{ACCOUNTABILITY OF FPR PROPERTY}

After the FPR project was terminated because of a diminished need for reprocessed uranium, the Laboratory's M\&O contractors took custody of nearly $\$ 54$ million in FPR property. We found that the project had acquired government furnished equipment consisting of 3,040 items valued at $\$ 32$ million and subcontract acquired property consisting of 8,360 items valued at $\$ 22$ million. We judgmentally reviewed 210 and 266 items from the respective lists of property. Our review showed that approximately $\$ 4.2$ million of the property was either not accounted for or inaccurately recorded in a Department approved property system. Specifically, Westinghouse did not account for $\$ 3.58$ million in government furnished equipment and MK-Ferguson did not account for approximately $\$ 655,000$ of the property acquired by the subcontractors.

\section{Westinghouse}

Westinghouse's accountability over property was incomplete and inaccurate. Our review showed Westinghouse had not placed 54 items valued at $\$ 3.2$ million in a Department approved property system. For example, it had not accounted for 4 evaporator vessels worth $\$ 481,000$ and had omitted 15 manipulators valued at $\$ 688,000$. In addition, Westinghouse's accountability over the property was inaccurate. For example, it included 17 extraction columns valued at $\$ 381,000$ in the property system even though the columns were excessed on May 2, 1994.

\section{MK-Ferguson}

MK-Ferguson also did not establish adequate accountability for property obtained as a result of the FPR project termination. For example, MK-Ferguson placed $\$ 655,000$ of FPR property in its own commercially developed database. However, MK-Ferguson never requested or made its database available to Idaho's Organizational Property Management Officer for approval. Significantly, the MK- 
Ferguson database did not have adequate controls to ensure the integrity and accuracy of data and did not interface with any Department approved system. Through this system, for example, one individual was issued property under 15 different configurations of the same name.

MK-Ferguson also did not account for FPR property when it was redistributed for use at the Laboratory. As MK-Ferguson removed property from its database for redistribution it was not added to any other database, including the Department approved property system operated by EG\&G. Our review of 224 sensitive and capital items redistributed within the Laboratory disclosed that 103 sensitive items and 27 capital items were not accounted for in any property system. The 103 sensitive items included computer hardware, power tools, portable welders, and typewriters while the 27 capital items included welders, flat bed trailers, heavy duty shop equipment and a Xerox copier. Because these items did not appear in any property system, there was a potential for undetected theft or loss.

\section{Unaccounted For Property}

In spite of the fact that a substantial amount of the property controlled by Westinghouse and MK-Ferguson was not adequately or accurately accounted for, we found that most of it could be physically located.

\section{PROMPT REUTILIZATION AND EXCESSING OF FPR PROPERTY}

Although the Laboratory's M\&O contractors made significant efforts to reutilize excess FPR property when the project was initially terminated, recent efforts to reutilize or excess the remaining property have diminished. A Westinghouse official, for example, believed that all FPR property was either retained, reutilized or excessed. Our analysis, however, showed that a significant amount of property was still in the FPR inventory. Of the initial 8,360 stock items, for example, approximately 2,700 items were still in the inventory and had neither been identified for redistribution nor excessed. We also observed that a majority of these items such as reinforcing steel, sheet metal, pipe fittings, nuts, tools, and piping were related to construction activities and, thus, appeared to be useful for other Laboratory projects.

We also found that very little property distributed outside the Laboratory was ever placed in the Department's excessing system which makes property available throughout the Department and to other Federal agencies. In fact, only 44 of the 1,490 stock items distributed outside the Laboratory were placed on this excess property system. The remaining items were either disposed of as scrap or distributed to other Departmental facilities on an informal basis. Westinghouse project management, for example, 
established contact points at various Departmental facilities; they then Iisted the unneeded FPR property by type and sent these lists to established contacts via letter and facsimile. All property requests from these lists were sent to the Westinghouse project manager who would ultimately approve the property transfer if the property was still available in inventory. As a result of using this procedure, the FPR property was not available to all elements of the Department or other Federal agencies. Thus, potential customers did not know that unneeded property was available and a lot of that property has gone unclaimed.

\section{ACCOUNTABILITY AND EXCESSING CONTROLS}

Inadequate accountability and excessing controls over FPR property existed because project management did not follow established Departmental property requirements and did not consistently adhere to the business practices established in local property management guidelines.

Under established Departmental property guidelines, for example, sensitive and capital property acquired by the Department is to be marked as "Property of U.S. Government" and assigned a control number for accountability purposes in EG\&G's approved property system. However, as the contractors received property relating to the FPR facility, these controls were overlooked. Thus, property was not accounted for properly. Our review of 215 judgmentally selected sensitive and capital items valued in excess of $\$ 531,000$ disclosed that 82 items (38 percent) had not been marked, tagged, or assigned a control number. This included three flatbed fifth wheel trailers valued at $\$ 21,819$ and specialized welding equipment valued in excess of $\$ 80,000$. Because this equipment was not identified, it was not entered into EG\&G's property system and, thus, could not be accounted for.

Additionally, items we verified as being placed in the property system had not been accounted for and forwarded to EG\&G in a timely manner. Some FPR property, for example was not included in the property system for up to ten months after it was received by the M\&O contractor. For example, a computer from the FPR inventory was transferred to a property custodian on July 30, 1993. However, according to Idaho's property system, the computer was not tagged and assigned a control number until May 1994.

Property management guidelines require that when the property is no longer needed, appropriate property officials be notified so that the unneeded property can be redistributed elsewhere. If the property is unclaimed, it is transferred to EG\&G for excessing. In contrast, the Utilization and Disposal Plan which was developed by project management following termination of the FPR project did not require adherence to established property management guidelines. Property was redistributed without the approval or involvement of property officials. Our review of the FPR Property Utilization and 
Disposal Plan disclosed that the redistribution or excessing of FPR property was solely controlled by project management, not knowledgeable property officials. The plan avoided established property management guidelines because FPR project managers felt that if property was turned over to property officials, the property would be scrapped or junked rather than reutilized. Consequently, property officials were not informed of excessing actions until the approval and transfer of the property had occurred.

\section{POTENTIAL FOR LOSS AND WASTE OF GOVERNMENT PROPERTY}

Inadequate controls over accountability of government property and excessing activities resulted in at least $\$ 4.2$ million of $\$ 21.2$ million (almost 20 percent) not being properly accounted for or reutilized within the Department. Although we were able to physically locate most of the property, the lack of property accountability rendered the property readily susceptible to undetected theft or loss. Furthermore, since the property was not marked, assigned a property control number, or placed in Idaho's approved property management system, the property was susceptible to undetected loss or theft. Also, because the property was not included in the property management system, it would not be identified in the periodic inventories performed on personal property. Thus, the property account in the financial statements for the Idaho operations office could be materially misstated. In addition, since the Laboratory has no accurate record of FPR property available, the property continues to be unused even though it is readily available. In fact, for an 18 month period, $\$ 43,000$ in common use items were purchased for the Laboratory when they were already available in the FPR inventory. 


\section{PART III}

\section{MANAGEMENT AND AUDITOR COMMENTS}

In responding to the Initial Draft Report, Management

concurred with the finding and recommendations. In fact, on April 19, 1995, Lockheed proposed an FPR Action Plan to appropriately identify and account for FPR property and the Idaho operations Office concurred with the plan. Thus, Management has already initiated corrective actions noted in this report. Management and auditor comments on the recommendations follow.

Recommendation 1

Management comments. Management concurred, stating that the wall-to-wall inventory, including count and reconciliation of FPR property, was completed by Lockheed on September 29, 1995. This activity accounted for 8,331 property items being inventoried. Idaho Operations office validation(using statistical sampling) of this inventory will be completed by October 31, 1995.

Auditor Comments. Management comments and actions are responsive to the recommendation.

\section{Recommendation 2}

Management Comments. Management concurred stating that marking, tagging, and accounting for FPR property mentioned in Recommendation No. I, above, will be completed by November 15, 1995. FPR property that was previously transferred and retained within the Laboratory will be counted, marked, and tagged as part of the Laboratory's wall-to-wall inventory program. Item count and reconciliation of these items will be completed by september 30 , 1996. The Laboratory's baseline inventory should be established by November 30, 1996.

Auditor Comments. Management's corrective actions are responsive to the recommendation.

Recommendation 3

Management Comments. Management concurred, stating that the FPR property mentioned in Recommendation Nos. 1 and 2 will be placed in the Laboratory's property management system by November 15, 1995. As the remaining FPR property is located during the Laboratory's wall-to-wall inventory, accountable property will be reconciled and placed in the property management system. This activity is part of the baseline inventory that should be established by November 30, 1996.

Auditor Comments. Management's corrective actions are responsive to the recommendation. 
Recommendation 4

Management Comments. Management concurred, stating that property not justified for retention is being excessed in accordance with Lockheed Property Management Requirements Manual No. 16. This manual was approved by Idaho and published by Lockheed in July, 1995.

Auditor Comments. Management's comments are responsive to the recommendation. 
IG Report No. WR-B-96-04

\section{CUSTOMER RESPONSE FORM}

The Office of Inspector General has a continuing interest in improving the usefulness of its products. We wish to make our reports as responsive as possible to our customers' requirements, and therefore ask that you consider sharing your thoughts with us. On the back of this form, you may suggest improvements to enhance the effectiveness of future reports. Please include answers to the following questions if they are applicable to you:

1. What additional background information about the selection, scheduling, scope, or procedures of the audit or inspection would have been helpful to the reader in understanding this report?

2. What additional information related to findings and recommendations could have been included in this report to assist management in implementing corrective actions?

3. What format, stylistic, or organizational changes might have made this report's overall message more clear to the reader?

4. What additional actions could the Office of Inspector General have taken on the issues discussed in this report which would have been helpful?

Please include your name and telephone number so that we may contact you should we have any questions about your comments.

Name Date

Telephone Organization

When you have completed this form, you may telefax it to the office of Inspector General at (202) 586-0948, or you may mail it to:

Office of Inspector General (IG-1)

Department of Energy

Washington, D.C. 20585

ATTN : Customer Relations

If you wish to discuss this report or your comments with a staff member of the Office of Inspector General, please contact Wilma Slaughter at (202) 586-1924. 